\title{
Disturbance and Climatic Effects on Red Spruce Community Dynamics at its Southern Continuous Range Margin
}

Red spruce (Picea rubens) populations experienced a synchronous rangewide decline in growth and vigor starting in the 1960s, likely caused by climate change and a combination of environmental disturbances. However, it is not yet known if populations continue to decline or have recovered. Red spruce growing near its southern range margin in Massachusetts is a species of concern, in light of the vulnerability to climate change. This study uses population data from 17 permanent plots coupled with tree-ring data to examine radial growth rates, determine the growth-climate relationship, and document disturbance events. Red spruce at these plots ranged from 90 to 184 years old, and comprised 15 to $29 \mathrm{~m}^{2} /$ ha basal area. Red spruce seedlings and saplings were common at plots with previously high overstory spruce abundance, indicating it could return to a more dominant position under favorable growing conditions. However, permanent plot measures over a 50 year time span did not indicate any consistent trends for changes in basal area or density for red spruce or other woody species. Climate data show that mean annual minimum, maximum, and summer temperatures have increased over the last 100 years. Dendroclimatological analyses indicated that red spruce growth was sensitive to both temperature and precipitation. Prior to the 1960 s, spruce at these sites showed a positive response to precipitation; however after a multi-year drought in the 1960s showed an increasingly negative correlation with precipitation. There has been a negative growth response to regional warming, as spruce radial growth was mostly constrained by increasing temperatures, potentially coupled with the associated increasing drought-dress. I suggest the change in climate response is potentially due to a physiological threshold response to increasing temperatures, which may cause spruce to continue to decline or be lost from the lower elevation sites, while the high elevation sites has a persistent spruce population. 
1 Relena Rose Ribbons ${ }^{1,2}$

2 Email address: rribbons@gmail.com

3 Institutions:

41 Harvard Forest, Harvard University, 324 N. Main St. Petersham, MA 01366

52 University of Massachusetts-Amherst, Environmental Conservation Department, 160

6 Holdsworth Way Amherst, MA 01002 


\section{$7 \quad$ Introduction}

9 (Loarie et al., 2009, Treyger \& Nowak, 2011). Climate change can profoundly alter forest

Climate and global change are altering forests across the northeastern United States ecosystems, including migration of species to maintain viable populations within specific-climate envelopes (Petit et al., 2008), and via altered seed production and regeneration rates due to increased carbon dioxide (Mohan et al., 2004). Tree species at their southern range margins are likely to experience heat stress and exhibit reduced growth, with boreal species at southern limits most at risk because they are already living at the edge of their environmental tolerance.

Evidence of vegetation communities changing with a warming climate in the eastern U.S. is already being observed (Beckage et al., 2008, McMahon et al., 2010, Treyger \& Nowak, 2011).

Decreased habitat suitability at southern latitudes, resulting from direct and indirect anthropogenic influences (e.g., non-sustainable forestry practices and climate change), might cause species to migrate north as climate becomes less favorable for their ideal growing conditions (Allen et al., 2010). In Massachusetts, red spruce forests are highly vulnerable to future climate change (Manomet Center for Conservation Sciences, 2010). In New England, annual temperatures have risen an average of $+0.08 \pm 0.01^{\circ} \mathrm{C}$ per decade over the last century, and $+0.25 \pm 0.01{ }^{\circ} \mathrm{C}$ per decade for the past three decades (Hayhoe \& Wake, 2007). The greatest changes over the last 35 years have been in winter, with almost a degree $C$ per decade increase (Hayhoe \& Wake, 2007).

In the 1980s, red spruce (Picea rubens Sarg.) experienced widespread decline in vigor (Hornbeck \& Smith, 1985, Reams \& Van Deusen, 1993, Scott et al., 1984) and health throughout New England (Battles et al., 2003, Siccama et al., 1982, Webb et al., 1993), and in disjunct populations in the Southern Appalachians (Cogbill \& White, 1991, Silver et al., 1991). Much of the research on red spruce within the Northeast focused on winter injury and the longterm influences of consecutive winter injury years (Lazarus et al., 2006) or the decline of high- 
32 elevation spruce-fir forests (Battles et al., 2003). Acid deposition effects on red spruce are well-

33 documented (Likens, Driscoll and Buso 1996), especially in high elevation forests where it is

34 linked directly to red spruce mortality and indirectly affects red spruce via increased

35 susceptibility to winter injury (Lazarus et al., 2006).

36 Moore et al. (2008) found evidence rebound (increased growth or vigor) of high-elevation

37 red spruce after declining in the southern Appalachians. Dendrochronology studies documented a

38 sustained gradual decrease in radial growth measurements throughout red spruce's northern range

39 (Cook et al., 1987, Johnson et al., 1988, Siccama et al., 1982). Previous studies document

40 decreased red spruce growth associated with high temperatures (Cook \& Johnson, 1989).

41 Hamburg and Cogbill (1988) noted red spruce displacement by hardwood species in the southern

42 Appalachians.

43 Two potential hypotheses for the spruce decline emerged: (1) stand history factors such as

44 pests, disturbance events including acid deposition, and natural stand aging processes; and (2)

45 climate change factors such as increased temperatures and drought-stress. Multiple factors, such

46 as climate and disturbance events, have contributed towards the widespread decline of red spruce

47 observed in many high-elevation populations (Van Deusen et al., 1991). While this decline

48 seemed fairly ubiquitous in red spruce populations, it is unclear if these populations are still

49 declining or have recovered from since the 1960s (Gavin et al., 2008, Lazarus et al., 2006),

50 especially at low-elevations.

51 Our study used red spruce tree-ring data coupled with population dynamics data

52 documented in continuous forest inventory (CFI) plots, to explore the largely unstudied long-term

53 dynamics of low-elevation (500-700 m. a.s.1.) red spruce in western Massachusetts. I used tree-

54 rings to investigate climate sensitivity to temperature and precipitation, the impact of climate

55 change on spruce growth rates at their southern continuous range margin, and past disturbance

56 history to elucidate the role of disturbance events andclimate change as the mechanism behind 
57 observed changes in spruce growth. Based on prior studies indicating spruce's sensitivity to warm

58 temperatures (negative correlations between temperature and ring-widths; Cook et al.1987,

59 Johnson et al. 1988) and the recent warming documented in New England, I tested two

60 hypotheses: (1) red spruce has declined in basal area and growth rates over the last 50 years in

61 Massachusetts; and (2) red spruce growth rates were negatively correlated with mean maximum

62 summer temperatures (heat stress).

63 Materials and Methods

64 Study Area

65 Red spruce in Massachusetts is located primarily in the western portion of the state

66 (Burns \& Honkala, 1990). Study sites were located in the Western Massachusetts Taconic

67 Mountains and Berkshire Plateau region, including portions of four State Forests: Mount

68 Greylock (MG), Savoy Mountain (SM), October Mountain (OM), and Middlefield Forest (MF)

69 (Fig. 1). These four spruce-dominated forests were selected because they contained Continuous

70 Forest Inventory (CFI) plots that were established in the 1960s to monitor the status of

71 Massachusetts state forests over time (see below).

72 The climate is characterized by cold winters (average $-5^{\circ} \mathrm{C}$ ) and moderately warm

73 summers (average $19^{\circ} \mathrm{C}$ ). Average annual rainfall is $109 \mathrm{~cm}, 55 \%$ of which falls from April to

74 September (Scanu, 1988). Average seasonal snowfall is $180 \mathrm{~cm}$. The Berkshire region is

75 underlain by igneous and metamorphic rocks, especially gneiss and schist (Scanu, 1988). Mount

76 Greylock is comprised mainly of granite and limestone bedrock. Soils are primarily rocky glacial

77 tills, with sand and gravel deposits proximate to waterways (Motts \& O'Brien, 1981). Plots at

78 Mount Greylock are located at higher elevations (678-978 $\mathrm{m}$ a.s.1.) than the three other forests

79 (540-724 m a.s.1.; Table 1). Field sites were established with permission from the Department of

80 Conservation and Recreation undertaken with a special use permit. 
81 Site selection and Vegetation Characterization

82 I selected seventeen field plots from a subset of 0.08 ha circular CFI plots established

83 every $0.8 \mathrm{~km}$ within a square grid across all State Forest Lands in 1960, except site MF which

84 was established in 2000. Since only one plot exists within MF (n=1), MF was excluded from all

85 stand dynamics statistics. Plots located on upland sites and containing forests characterized by at

86 least $50 \%$ spruce-fir or red spruce basal area at the time of the last forest survey in 2000 , were

87 used for this study. The 17 plots were relocated using a handheld GPS unit and plot boundaries

88 were re-established for the vegetation inventory from May through September 2010. At each CFI

89 plot, all overstory trees $>12.7 \mathrm{~cm}$ diameter at breast height $(\mathrm{DBH} ; 1.37 \mathrm{~m})$ were measured and

90 identified to species. Efforts were made to relocate previously numbered or painted overstory

91 trees within each plot, to match exact tree measurements with past inventories; however, paint

92 had worn off most trees within plots so individual tree diameter comparisons were not made. All

93 saplings $(5-12.7 \mathrm{~cm} \mathrm{DBH})$ within the plot were tallied and identified to species. In addition,

94 percent cover of seedling and shrub species were estimated in a $5 \mathrm{~m}$ radius subplot located in the

95 plot center, to determine regeneration of red spruce and other tree species. Dead spruce trees were

96 tallied, although individual tree-mortality comparisons were not made due to the loss of

97 individual tree markers and painted numbers. Total basal area, red spruce basal area, and red

98 spruce density were calculated for each sampling period (1960, 1980, 2000, and 2010) using past

99 CFI data. Additionally, basal area and density of all trees except red spruce were calculated for

100 each sampling period. Relative importance values were calculated at each site as the sum of

101 relative basal area and relative density for each species. Stand dynamics data were analyzed using

102 linear mixed models in R (R Core Team, 2013) with the nlme package (Pinheiro et al. 2013).

103 Nomenclature follows Gleason and Cronquist (1991). 

111 climate analysis.

\section{2}

\section{Field data collection} (Holmes, 1981).

\section{Data Analysis}

All overstory red spruce $(>10 \mathrm{~cm} \mathrm{DBH})$ trees within each plot were cored at DBH with an increment borer. When $<10$ red spruce occurred within a plot, additional red spruce located outside the plot were cored until at least 10 trees were obtained from each site). Two cores per tree were extracted to identify any locally absent rings and to provide a better estimation of whole-tree radial growth. 213 cores were successfully cross-dated and used for disturbance and

\section{Sample preparation and measurements}

All cores were dried, mounted, and sanded using progressively finer sand paper, up to 600-grit. Each core was visually crossdated within each tree first using the list method (Yamaguchi, 1991) and cores were compared among trees within each plot. Cores were then measured to $0.001 \mathrm{~mm}$ precision using to an Olympus SZ40 microscope and a Velmex measuring system (Velmex, East Bloomfield, NY, USA) interfaced with Measure J2X software . Ring widths were used to statistically verify the accurate dating of all tree rings using Spearman's correlation analyses (with a critical r-value of 0.33 ) available in the COFECHA tree-ring software

After verification using COFECHA, red spruce chronologies were constructed for each forest using the program ARSTAN (Cook, 1985). A window of 32 years, with 16-year overlaps was used for the common period of 1930-2009, with a variance stabilization of one-third the length of the longest core. Data were first detrended with a negative exponential curve, then detrended with a $-2 / 3$ smoothing spline, with interactive detrending used on individual cores when necessary (e.g., when growth trends appeared inflated by poorly fitted detrending curves). Residual chronologies from ARSTAN- averaged ring-width indices across an entire sampling site with autocorrelation removed- was used for climate analysis. 
131 against mean monthly maximum and minimum temperature and precipitation from the prior 132 March to October of the current year from 1896 to 2009. Climate data from the PRISM project

133 (PRISM Climate Group, 2010) were correlated with tree ring widths using Dendroclim2002

134 moving interval analysis to analyze the chronologies from the previous March to the current

135 October months using a moving window of 40 years (Biondi \& Waikul, 2004). Only significant

136 correlation values are plotted in the DendroClim2002 output, which has red to indicated

137 significantly positive values, and blue to indicate significantly negative values. To assess whether

138 sites exhibit temporal stability in their climate response I examined the DendroClim output

139 graphs looking for consistent colored bars over the entire time period which suggests a

140 temporally stable response, or vice versa to establish a temporally non-stable climate response. I

141 also used response function analysis (RFA), a multiple regression technique that uses principal

142 components of monthly climate data to estimate indexed values of ring widths and examine how

143 climate influenced radial growth over the entire time period (Fritts, 1976). RFA was

144 implemented in DendroClim and uses bootstrapping techniques to determine significance levels

$145 \quad($ alpha $=0.051$; Speer 2010).

146 Ring width chronologies were used to calculate average yearly growth rates in basal area

147 increment (BAI expressed as $\mathrm{mm} 2$ /year). To calculate BAI, the radius of an individual tree is

148 multiplied by the number Pi (3.14) to equal the area of the circle. The annual increment for year

$149 \mathrm{X}$ is defined by the following equation: $\mathrm{X}-(\mathrm{X}-1) /(\mathrm{X}-1)$, where $\mathrm{X}$ is the basal area at year $\mathrm{X}$ (last

150 year of growth) and X-1 is the basal area of the tree measured up to the year previous to $\mathrm{X}$

151 (Johnson and Abrams 2009).

152 Stand disturbance dynamics within each forest were also reconstructed by evaluating all

153 cores separately for abrupt growth releases using the criteria established by Lorimer and Frelich

154 (1989), who defined a "major sustained release" as an average growth increase $\geq 100 \%$ lasting at 
155 least $15 \mathrm{yr}$ relative to the previous $15 \mathrm{yr}$ and a "moderate temporary release" as an average

156 growth increase $\geq 50 \%$ lasting $10-15 \mathrm{yr}$ relative to the previous $10-15 \mathrm{yr}$. In addition, abrupt

157 growth decreases $\geq 50 \%$ lasting $10 \mathrm{yr}$ relative to the previous $10 \mathrm{yr}$ were tallied for each canopy

158 tree as an indication of canopy damage (D'Amato and Orwig $2008 \mathrm{cf}$.). The use of 10- and 15-

159 year windows within these release criteria removed the effects of short-term growth responses

160 due to climatic events such as droughts (Lorimer \& Frelich, 1989, Nowacki \& Abrams, 1997).

161 Disturbance chronologies were constructed for each study area by tallying the number of release

162 and damage events by decade (Lorimer \& Frelich, 1989). Disturbances were only counted from

163 one core per tree (Copenheaver et al., 2009).

\section{Results and Discussion}

165 Stand composition

166 Over the past 50 years, total stand basal area differed across sampling years $(\mathrm{p}=0.04)$ but

167 not among forests $(\mathrm{p}=0.079)$, while total stand density remained largely stable across sampling

168 years $(p=0.45$; Fig. 2 a $-g)$, and among forests $(p=0.63)$. Red spruce basal area differed

169 significantly over time $(\mathrm{p}=0.02)$ but remained relatively constant at MG, increased at SF, and

170 decreased at OM and MF forests, and did not significantly vary among forests over time $(\mathrm{p}=$

171 0.191). Basal area of all other species did not significantly differ among forests $(\mathrm{p}=0.71)$,

172 sampling year $(0.20)$, or interact over time $(\mathrm{p}=0.23)$. Non-spruce basal area declined by at least

$17350 \%$ at MG and MF forests, increased slightly at SF and increased by over $100 \%$ at OM. Red

174 spruce density differed significantly over time $(p=0.02)$ among forests $(p=0.005)$, with declines

175 at $\mathrm{OM}$ and SF forests, while MG increased in density (Fig. 2).

$176 \quad$ Sharp declines in red spruce densities were observed at OM after 1980 (272 to 168

177 stems/ha) and at MF since the 1980s (790 to 111 stems/ha; Table 2). The density of all other

178 species declined $20-50 \%$ at three of the four study sites between 2000 and 2010; however the 
179 density of other species did not significantly differ since 1960 either by forest $(\mathrm{p}=0.80)$ or

180 sampling year $(p=0.72)$. At MF forest, the density of species other than spruce increased

181 approximately 15\%. Paper birch relative importance increased in each forest, while American

182 beech and red maple increased in importance at three of the forests (Table 2). Saplings present

183 within sampled forests were largely American beech, red maple, and balsam fir. Some sites still

184 supported a healthy population of understory red spruce, indicated by abundant red spruce

185 saplings (216 -262/ha).

\section{Radial Growth and Climate Response}

Mean maximum, minimum, and mean summer temperatures have increased over the past

century at all sites. There has been an average increase of $1^{\circ} \mathrm{C}$ over the past century in mean

temperature (Fig. S7). Precipitation remained relatively stable with a slight increase over the past

century, except for a prolonged decrease in total precipitation during a lengthy drought in the

1960s (Fig. S6). Raw red spruce ring widths for each forest (Fig S1) show trends of declining

radial growth rates over time, which is consistent with natural decreases in growth as trees

mature. Detrending was used to remove growth-trends which extend beyond a 32 year frequency,

194 so as to emphasize decadal-to-annual variability in tree growth rates. This process rules out

195 natural declines in ring-widths due to age and suggests an external force (such as climate or

196 environmental disturbance) limited spruce growth. The ARSTAN chronologies (Figs. S2-S3) are

197 more conservative in response to climate parameters, and were used for remaining analyses.

198 Basal area increment (BAI) was calculated using both cores from a tree, averaged across

199 plots and within forests (Fig. 6). BAI curves show that on average, SF and OM forests declined

200 over the last century, while MF and MG increased in BAI. Response Function Analysis (RFA) for

201 regional climate data showed a significantly positive response of spruce radial growth with

202 maximum monthly temperatures in May, and negative responses with maximum temperature in 
203 July and October precipitation (Fig. 6). RFA responses to temperature and precipitation differed

204 across the four forests (Figs. S8-S11), with specific trends explained below.

205 Forest-level trends in BAI and RFA

206 BAI at MG has continued to increase suggesting that red spruce at these sites may be

207 locally adapted to stressful conditions and are more resilient to climatic changes. Red spruce are

208 likely to continue to demonstrate positive growth at MG. In contrast, OM BAI declined for a

209 decade from the mid-1970's to 1980's and again from 1998 to present, reinforcing the theory that

210 red spruce at this forest are declining. SF BAI declined from the mid 1960's to mid 1980's, where

211 it began to increase until 1998 when these spruce experienced a dramatic reduction in BAI. Since

2121998 SF red spruce BAI has increased but it still quite variable. MF BAI has steadily increased,

213 suggesting red spruce at this forest experience favorable growing conditions. Taken together, only

214 MG and MF forests have increasing BAI, while OM and SF show trends of declining BAI.

215 Similar to the regional response, MG RFA had a significantly positive relationship with

216 maximum temperatures in May and a negative relationship with precipitation in October. OM

217 RFA showed spruce was negatively related to maximum temperatures in July and positively

218 related with minimum temperatures in December, and had no significant growth response to

219 precipitation. SF RFA had a significant response to November maximum temperatures, with no

220 significant responses to minimum temperatures and precipitation. MF RFA had a significant

221 positive response to precipitation in August, and no significant responses to temperatures.

222 Temporal stability in climate-growth response at a regional and forest-scale

223 Moving interval analysis (using a moving 40 year window) with the regional ARSTAN

224 chronologies showed that spruce growth had a consistent positive correlation (as indicated by

225 dark red bards) with wintertime temperatures from the late 1930s until the late 1960s. After the

226 1960's spruce growth was then negatively correlated with the previous years' summer

227 temperatures until the early 1990s, after which it was positively associated with previous years' 
228 May temperatures (Fig. 5). Regional spruce growth was positively associated with current years'

229 August precipitation for the last 3 decades. Red spruce growth at MG was positively correlated

230 with average maximum and minimum winter temperatures from November of the previous year

231 to February of the current growing year, from the 1936 until 1966 (Fig. 3). After 1956, radial

232 growth was negatively correlated with maximum March temperatures from the previous year, as

233 indicated by the dark blue bars, remained consistently negative until 1986, after which the

234 relationship was no longer significant. Previous year's July temperatures showed a marginally

235 significant negative relationship with growth beginning in 1966 to the mid-1990s at MG (Fig. 3).

236 The OM ARSTAN chronology showed a positive relationship to minimum and maximum

237 winter temperatures from the previous November to the current February (Fig. 3). I observed a

238 strong negative response with spruce growth and current and previous summer minimum

239 temperatures from 1970 to around 1990 and a similar response to previous year's maximum

240 temperatures after 1986. The SF ARSTAN chronology showed a positive relationship between

241 radial growth and minimum February temperature from 1960 until 1984 and with minimum

242 September temperatures from the early 1970s until the late 1990s (Fig. 3). A strong negative

243 correlation between growth and current year July maximum temperatures was observed until the

244 mid-1980's after which the previous year's July maximum temperatures show a consistent

245 negative response (Fig. 3). Previous March minimum temperatures were also negatively

246 correlated with radial growth, which was consistent until the 1990s (Fig. 3), when the relationship

247 deteriorated. MF exhibited weak correlations between growth and maximum temperatures, with

248 no strong patterns emerging (Fig. 3). The MF residual chronology was positively correlated with

249 both current and previous year's September minimum temperature from the 1930s until the mid-

250 1960s, after which there was no significant relationship.

251 Spruce growth relationships with precipitation varied among sites. Until 1956, MG

252 growth was positively correlated with January precipitation (Fig. 4) and then after 1976 was 
253 negatively correlated with previous year's October precipitation. From the mid 1960s and 1970s

254 to the present, spruce growth was positively correlated with current August precipitation at the $255 \mathrm{MG}, \mathrm{MF}$, and SF sites and with previous August precipitation at both the MF and SF sites. No 256 strong correlations existed between precipitation and radial growth at $\mathrm{OM}$ for more than a few

257 years, except for a negative correlation with June precipitation from the mid-1950s to the late 258 1970s, suggesting that precipitation was not the primary limiting factor influencing radial growth 259 at this site (Fig. 4).

Disturbance History

The four sites I examined experienced varied radial growth dynamics across a gradient of 262 disturbance (Fig. 8). MG experienced the most disturbance events with an average of 1.08 263 moderate, 0.58 major, and 1.30 declines per tree, followed by OM with 0.75 moderate, 0.63 264 major, and 1.65 declines per tree, SF with 0.67 moderate, 0.36 major, and 1.22 declines per tree, 265 and MF with 0.35 moderate, no major, and 1.30 declines per tree. Prior to 1900 sampling depth 266 was low, so I did not attempt to interpret detailed stand histories during this time. Following 267 1900, a high \% of spruce experienced moderate growth releases in the 1920s and 1930s and both 268 moderate and major growth releases in the 1970s and 1980s (Fig. 8). Low-level disturbance was 269 detected in most other decades. Significant periods of growth decreases occurred at MG during 270 the 1920s, 1960s, and the 1990s. At MG, OM, and SF, I observed a pulse of moderate and minor 271 disturbance events in the 1930s, which is the decade of the 1938 Hurricane (Boose et al., 1994, 272 D'Amato et al., 2008). During this decade, disturbance events were noted in $25 \%$ of trees at MG, $27322 \%$ of trees at $\mathrm{OM}$, and $16 \%$ of trees at SF. and 2 periods of moderate increases in the 1920s and 1980s. Significant growth reductions were

276 seen in OM spruces during the 1950s, 1970s, and especially the 1990s, when all sampled trees 277 exhibited growth reductions during this decade. This is consistent with the stand dynamics 
278 hypothesis for red spruce decline as supported by Ream and Van Deusen (1993), which contends

279 that the new growth released in the 1920's and 1930's at these sites naturally slowed in growth

280 and increased competition led to some mortality. SF spruce experienced growth increases during

281 the 1940s and 1950s and over $80 \%$ of trees experienced growth declines during the 1960 s.

282 Unlike the other sites, very little disturbance was detected in MF spruce cores, including no major

283 growth releases in any decade examined. The most dramatic period of growth declines occurred

284 at 3 of the 4 forests during the 1990 s, when $70-100 \%$ of the trees experienced sharp growth 285 reductions.

286 Over the last 50 years, some of the red spruce forests in western Massachusetts have

287 declined in radial growth and density while maintaining basal area in the overstory. At some

288 forests the understory is largely not red spruce seedlings and saplings, but instead a variety of

289 northern hardwood species. Basal area increment has declined at some forests (OM and SF), but

290 others (MG and MF) have steadily increased and do not exhibit extensive declines in basal area

291 increment. Some red spruce trees have shifted their climate-growth responses, as demonstrated

292 by moving interval analyses and the temporally unstable relationships between temperature,

293 precipitation and ring widths. Red spruce in this study were located at lower elevations (500-700

294 m. a.s.1.) than sites studied in the Adirondacks, Vermont, and Appalachian mountains. Additional

295 studies in low-elevation red spruce populations will help to discern whether climate or

296 physiology contributes to the red spruce growth decline widely observed in the 1960s-1980s

297 Red spruce populations at some forests have sustained radial growth declines since the

298 1940s -1960s period (see raw-ring widths for each forest in Fig. S1). Tree growth rates naturally

299 decrease as they age or increase in size (Fritts, 1976), so a trend of declining radial growth or ring

300 increment is expected; however since these populations are not very old, the patterns of declining

301 ring-widths are not explained by allometry and are not common to all populations. During the

302 1960s the Northeast experienced a severe drought, which could have contributed to spruce water 
303 limitation. Some individual trees rebounded in radial growth beginning in the 1990s (Figs. S2-

304 S3); likely due to stand disturbance events such as growth releases and decreased proximate 305 competition within the stand.

306 MG, OM, and SF showed a common trend of sudden growth declines in the 1960s

307 through the 1980s which corresponds the observed widespread red spruce decline in the

308 northeast. The highest maximum temperatures were observed during the 1990 s and the residual

309 ARSTAN chronology also shows the lowest values for spruce radial growth during this time

310 period, supporting the theory that the increased temperatures have led to decreased radial growth.

311 Despite mortality of older red spruce, MG sites show continued spruce establishment and

312 recruitment, which is why stand density remained consistent, which is consistent with recent

313 findings at other high-elevation or higher latitude sites (van Doorn et al. 2011, Kosiba et al.

314 2013). In contrast, several OM sites have declined in both overstory and understory spruce

315 density, reducing the likelihood of spruce retention. SF and MF sites have maintained a red

316 spruce canopy but have little to no spruce regeneration, making it less likely that red spruce will

317 persist.

318 Non-stable climate growth relationships

319 Temperature had a much stronger influence on red spruce radial growth than precipitation

320 over time across the region and the 4 forests (Figs. 3-5), although this relationship was not

321 temporally stable. While a consistent climate-growth relationship was observed across the

322 Massachusetts sites during the first half of the twentieth century, a distinct shift in this

323 relationship began in the 1960s, but was variable across sites. Non-stable climate relationships

324 can be explained by either climate change or a physiological tolerance/ threshold response as

325 suggested by Cook and Johnson (1989). The physiological threshold response can be best

326 explained as stress-induced physiological changes within trees that alter how they grow in

327 response to climate (e.g. after an extreme drought trees may decrease their water uptake and 
328

329

330

331

332

333

334

335

336

337

338

339

340

341

342

343

344

345

346

347

348

349

350

351

352

efficiency; D'Arrigo et al., 2008, Driscoll et al., 2005, Wilmking et al., 2005, Wilmking et al., 2004). Studies have documented unstable climate responses for other red spruce populations (Johnson et al. 1988, Conkey, 1986, Conkey, 1988) and several other boreal species (AndreuHayles et al., 2011, Shi et al., 2010) and attributed them to stand history events such as logging or past land use which were consistent across sites. The variability in responses across our sites supports a climatic-threshold response, since our disturbance history analysis shows periods of release but not consistently across sites.

Changes in maximum and minimum winter temperatures influenced red spruce radial growth over the past century at these sites. Prior to the 1960s, spruce growth was positively associated with minimum and maximum winter temperatures (Fig. 3). After the 1960s, there was a distinct shift with spruce growth negatively correlated with maximum and minimum summer temperatures. This suggests growth was limited by the high summer temperatures in the 1960s, either directly by making it too warm for the trees to grow optimally; or indirectly because there was a concurrent large-scale drought during this decade. These trends are similar to Cook et al. (1987) and McLaughlin et al. (1987), who observed that late summer temperatures (previous July maximum) negatively influenced red spruce radial growth in Northeastern forests.

\section{Precipitation}

Prior to the 1960 s, red spruce at all sites showed a positive response to precipitation and after the 1960s drought, MG and OM showed an increasingly negative correlation with precipitation, while SF and MF continue to have a positive correlation with precipitation. The threshold response model proposed by Cook and Johnson (1989) is supported by these data. The 1960s drought represented a prominent climate event, after which precipitation was no longer a limiting factor at MG and $\mathrm{OM}$ sites, and increased precipitation was correlated with decreased ring-widths at these sites. High-elevation forests tend to be more limited by temperature (Schweingruber, 1996), and low-elevation sites are typically more sensitive to precipitation 
353 (Cook \& Johnson, 1989). Webb et al. (1993) found that range-edge red spruce in bog sites were

354 slower-growing but had more robust populations, while upland sites supported increasingly

355 drought sensitive populations. In contrast, our study sites displayed decreasing drought sensitivity

356 after the extensive drought of 1960 . Only one forest, MF, showed a significant precipitation

357 response in DendroClim, unique in comparison to the three other forests sampled.

358 Prior to 1960, growth at MF was positively correlated with precipitation from March of

359 the previous year. After 1960, MF had a strong positive correlation with precipitation from the

360 previous September and August of the current growing season with radial growth in red spruce at

361 MF. The precipitation- growth response at MF shifts after the 1960s, similar to the pattern of

362 temperature response which shifts in the 1960s, suggesting a precipitation threshold exists at MF.

363 Buntgen et al. (2006) found a similar lack of stability between the growth/climate relationships

364 for populations of Norway spruce, and suggest an increasing sensitivity to drought could be

365 altering the climate-growth response due to increased evapotranspiration. While I did not directly

366 measure rates of evapotranspiration, drought stress is a plausible explanation for declining radial

367 growth of red spruce in some sites in Western Massachusetts forests-specifically induced by the

368 1960s drought, while other sites started to decline in the 1940s.

369 Non-climatic environmental stressors

370 A variety of factors influence spruce growth in western Massachusetts where climate

371 change is likely to have a large influence on populations at their range margin. The climatic-

372 threshold theory states that trees shift their growth patterns and carbon allocation (i.e., ring

373 widths) in response to climate conditions. This theory specifically predicates that climate is the

374 main stressor that has induced physiological changes in tree growth (Cook and Johnson 1989),

375 and accurately describes the patterns in ring-widths observed at our sites although it is possible

376 that forest dynamics are also contributing factors. In contrast, I would expect uniform responses

377 to environmental triggers like pollution or acid deposition across all sites, which I do not see in 
378 Western Massachusetts. Pollution would also not discriminate across stand types (second-growth

379 vs. old-growth) and some studies have shown the widespread decline to be especially prevalent in

380 second-growth stands (Van Deusen, 1987).

381 Acid deposition has been shown to influence other red spruce populations, however at our

382 sites, I observed no visible symptoms of acid deposition (needle reddening or winter injury) and

383 it was not recorded historically in CFI notes. Additional foliar and soil chemistry studies could

384 provide insights into nutrient cycling and other aspects of these red spruce forests, and should be

385 pursued to tease apart the potential effects in Western Massachusetts. In New York and Vermont,

386 acid deposition was considered to be more of a driving force for decline of red spruce, especially

387 because of altered foliar and soil chemistry (Battles et al., 2003, McLaughlin et al., 1987). In

388 those high elevation forests, acid deposition may have exacerbated red spruce decline, and with

389 the introduction of the clean air act in 1970 a recovery of high-elevation red spruce populations

390 would have been likely (Van Deusen, 1990). While this mechanism may be an important driver in

391 other areas, we do not see evidence for acid deposition leading to decline in western

392 Massachusetts red spruce populations. I observed that red spruce importance values were

393 consistent over time, and found no evidence of a decadal-scale decline in basal area increment

394 from the 1960's to the present, which would have supported an acid deposition explanation.

\section{Conclusions}

Red spruce may be especially susceptible to climate change in Massachusetts because

397 populations are isolated geographically, and may not have the topographic landscape conducive

398 to tracking climate, which could lead to a range contraction (Morin et al., 2008). Conversely,

399 species such as tulip poplar (Liriodendron tulipifera) or pin oaks (Quercus palustris) which are at

400 their northern range limit in Massachusetts may enjoy enhanced growth as climate continues to

401 warm. Western Massachusetts red spruce chronologies demonstrate a changing climate-growth

402 relationship. Temperature stress increases susceptibility to drought-induced growth reductions, 
403 making precipitation a limiting factor when temperatures increase. This shift from positive to

404 negative growth correlations reinforces the hypothesis that the climate where these trees

405 established has changed over the past 100 years, and is now warmer than ideal for growing

406 conditions of red spruce. It is likely that a variety of co-factors have influenced red spruce

407 populations, including a reduction of pollution levels associated with acid deposition, which

408 might alleviate growth stress, and competition-induced red spruce mortality. Radial growth

409 declines and reduced seedling and sapling abundance, suggests that red spruce may not maintain

410 viable populations in Massachusetts forests at low-elevations. However, red spruce will persist at

411 high-elevation sites like Mount Greylock, where spruce regeneration and basal area are

412 increasing.

\section{Acknowledgements}

414 Thank you to advisers Matthew Kelty, David Orwig, Neil Pederson, and Glenn Motzkin for

415 assistance with design and analysis. Thank you to Israel Del Toro for field and laboratory

416 assistance. Thank you to Henri Grissino-Mayer, Peter White, and Israel Del Toro for comments

417 on earlier versions of this manuscript. Thank you to Kerry Woods, Daniel Gavin, and an

418 anonymous reviewer for helpful revisions on this manuscript. 
420

421

422

423

424

425

426

427

428

429

430

431

432

433

434

435

436

437

438

439

440

441

442

443

444

445

446

447

448

449

450

451

452

453

454

455

456

457

458

459

460

461

462

463
Allen CD, Macalady AK, Chenchouni H.. 2010. A global overview of drought and heat-induced tree mortality reveals emerging climate change risks for forests. Forest Ecology and Management, 259, 660-684.

Andreu-Hayles L, D'arrigo R, Anchukaitis KJ, Beck PSA, Frank D, Goetz S. 2011. Varying boreal forest response to Arctic environmental change at the Firth River, Alaska. Environmental Research Letters, 6.

Battles JJ, Fahey TJ, Siccama TG, Johnson AH. 2003. Community and population dynamics of spruce-fir forests on Whiteface Mountain, New York: recent trends, 1985-2000. Canadian Journal of Forest Research-Revue Canadienne De Recherche Forestiere, 33, 54-63.

Beckage B, Osborne B, Gavin DG, Pucko C, Siccama T, Perkins T. 2008. A rapid upward shift of a forest ecotone during 40 years of warming in the Green Mountains of Vermont. Proceedings of the National Academy of Sciences of the United States of America, 105, 4197-4202.

Biondi F, Waikul K. 2004. DENDROCLIM2002: A C++ program for statistical calibration of climate signals in tree-ring chronologies. Computers \& Geosciences, 30, 303-311.

Boose ER, Foster DR, Fluet M. 1994. Hurricane impacts to tropical and temperate forest landscapes. Ecological Monographs, 64, 369-400.

Burns R, Honkala BH. 1990. Silvics of North America: 1. Conifers; 2. Hardwoods.. Agriculture Handbook 654, U.S. Dept. of Agriculture, Forest Service, Washington, D.C., 2, 877.

Cogbill CV, White PS. 1991. The latitude-elevation relationship for spruce-fir forest and treeline along the Appalachian mountain chain. Vegetatio, 94, 153-175.

Conkey LE. 1986. Red spruce tree-ring widths and dnsities in eastern North America as indicators of past climate. Quaternary Research, 26, 232-243.

Conkey LE. 1988. Decline in old-growth red spruce in western Maine- an analysis of wood density and climate. Canadian Journal of Forest Research-Revue Canadienne De Recherche Forestiere, 18, 1063-1068.

Cook ER, Johnson AH. 1989. Climate change and forest decline- a review of the red spruce case. Water Air and Soil Pollution, 48, 127-140.

Cook ER, Johnson AH, Blasing TJ. 1987. Forest decline: modeling the effect of climate in tree rings. Tree Physiology, 3, 27-40.

Cook ER, P.J. Krusic, R.H. Holmes, K.Peters. 1985. Program ARSTAN.

Copenheaver CA, Black BA, Stine MB, Mcmanamay RH, Bartens J. 2009. Identifying dendroecological growth releases in American beech, jack pine, and white oak: Withintree sampling strategy. Forest Ecology and Management, 257, 2235-2240.

D'amato AW, Orwig DA, Foster DR. 2008. The influence of successional processes and disturbance on the structure of Tsuga Canadensis forests. Ecological Applications, 18, 1182-1199.

D'arrigo R, Wilson R, Liepert B, Cherubini P. 2008. On the 'Divergence Problem' in Northern Forests: A review of the tree-ring evidence and possible causes. Global and Planetary Change, 60, 289-305.

Daniels LD, Maertens TB, Stan AB, Mccloskey SPJ, Cochrane JD, Gray RW. 2011. Direct and indirect impacts of climate change on forests: three case studies from British Columbia. Canadian Journal of Plant Pathology-Revue Canadienne De Phytopathologie, 33, 108116. 
Driscoll WW, Wiles GC, D'arrigo RD, Wilmking M. 2005. Divergent tree growth response to recent climatic warming, Lake Clark National Park and Preserve, Alaska. Geophysical Research Letters, 32.

Easterling DR, Meehl GA, Parmesan C, Changnon SA, Karl TR, Mearns LO. 2000. Climate extremes: Observations, modeling, and impacts. Science, 289, 2068-2074.

Frich P, Alexander LV, Della-Marta P, Gleason B, Haylock M, Tank A, Peterson T. 2002. Observed coherent changes in climatic extremes during the second half of the twentieth century. Climate Research, 19, 193-212.

Fritts HC. 1976. Tree rings and climate, London; New York, Academic Press.

Gavin DG, Beckage B, Osborne B. 2008. Forest dynamics and the growth decline of red spruce and sugar maple on Bolton Mountain, Vermont: a comparison of modeling methods. Canadian Journal of Forest Research-Revue Canadienne De Recherche Forestiere, 38, 2635-2649.

Hamburg SP, Cogbill CV. 1988. Historical decline of red spruce population and climatic warming. Nature, 331, 428-431.

Hayhoe KEA, Wake CPH, T. G. Luo, L. F. Schwartz, M. D., Sheffield, J., Wood, E., Anderson, B., Bradbury, J., Degaetano, A., Troy, T. J., and Wolfe, D. 2007. Past and future changes in climate and hydrological indicators in the US Northeast. Climate Dynamics, 28, 381407.

Holmes R. 1981. Computer assisted quality control in tree-ring dating and measurement. TreeRing Bulletin, 44, 69-75.

Hornbeck JW, Smith RB. 1985. Documentation of red spruce growth decline. Canadian Journal of Forest Research-Revue Canadienne De Recherche Forestiere, 15, 1199-1201.

Johnson AH, Cook ER, Siccama TG. 1988. Climate and red spruce growth and decline in the northern Appalachians. Proceedings of the National Academy of Sciences of the United States of America, 85, 5369-5373.

Johnson, S.E. Abrams, M.D. 2009. Basal area increment trends across age classes for two longlived tree species in the eastern U.S. in Kaczka R, Malik I, Owczarek P, Gärtner, H, Helle G, Heinrich, I (eds.)TRACE - Tree Rings in Archaeology, Climatology and Ecology, Vol. 7. GFZ Potsdam, Scientific Technical Report STR 09/03, Potsdam, pp. 226.

Kosiba AM, Schaberg PG, Hawley GJ, Hansen CF (2013) Quantifying the legacy of foliar winter injury on woody aboveground carbon sequestration of red spruce trees. Forest Ecology and Management, 302, 363-371.

Lazarus BE, Schaberg PG, Hawley GJ, Dehayes DH. 2006. Landscape-scale spatial patterns of winter injury to red spruce foliage in a year of heavy region-wide injury. Canadian Journal of Forest Research-Revue Canadienne De Recherche Forestiere, 36, 142-152.

Likens GE, Driscoll CT, Buso DC (1996) Long-term effects of acid rain: Response and recovery of a forest ecosystem. Science, 272, 244-246.

Loarie SR, Duffy PB, Hamilton H, Asner GP, Field CB, Ackerly DD. 2009. The velocity of climate change. Nature, 462, 1052-U1111.

Lorimer CG, Frelich LE. 1989. A methodology for estimating canopy disturbance freuency and intensity in dense temperate forests. Canadian Journal of Forest Research-Revue Canadienne De Recherche Forestiere, 19, 651-663.

The Manomet Center for Conservation Sciences and the Massachusetts Division of Fisheries and Wildlife. 2010. Climate change and Massachusetts fish and wildlife: Volume 2 Habitat and Species Vulnerability [Climate Change and Massachusetts Fish and Wildlife Report]. Retrieved from CAKE: http://www.cakex.org/virtual-library/2258 
511 Mclaughlin SB, Downing DJ, Blasing TJ, Cook ER, Adams HS. 1987. An analysis of climate and

512 competition as contributors to decline of re spruce in high elevation Appalachian forests

513 of the eastern United States. Oecologia, 72, 487-501.

514 Mcmahon SM, Parker GG, Miller DR. 2010. Evidence for a recent increase in forest growth.

$515 \quad$ Proceedings of the National Academy of Sciences of the United States of America, 107,

$516 \quad 3611-3615$.

517 Mohan JE, Clark JS, Schlesinger WH. 2004. Genetic variation in germination, growth, and

518

519

520

521

522

523

524

525

526

527

528

529

530

531

532

533

534

535

536

537

538

539

540

541

542

543

544

545

546

547

548

549

550

551

552

553

554

555

556 survivorship of red maple in response to subambient through elevated atmospheric $\mathrm{CO} 2$. Global Change Biology, 10, 233-247.

Moore PT, Van Miegroet H, Nicholas NS. 2008. Examination of forest recovery scenarios in a southern Appalachian Picea-Abies forest. Forestry, 81, 183-194.

Morin X, Viner D, Chuine I. 2008. Tree species range shifts at a continental scale: new predictive insights from a process-based model. Journal of Ecology, 96, 784-794.

Motts W, O'brien AO. 1981. Geology and Hydrology of Wetlands in Massachusetts. Amherst, Massachusets, University of Massachusetts, Amherst.

Nowacki GJ, Abrams MD. 1997. Radial-growth averaging criteria for reconstructing disturbance histories from presettlement-origin oaks. Ecological Monographs, 67, 225-249.

Petit RJ, Hu FS, Dick CW. 2008. Forests of the past: A window to future changes. Science, 320, 1450-1452.

Pinheiro J, Bates D, DebRoy S, Sarkar D, and the R Development Core Team (2013). nlme: Linear and Nonlinear Mixed Effects Models. R package version 3.1-111.

Prism Climate Group, Oregon State University. http://prism.oregonstate.edu, created May 2011.

R Core Team (2013). R: A language and environment for statistical computing. R Foundation for Statistical Computing, Vienna, Austria. URL http://www.R-project.org/.

Reams GA, Van Deusen PC. 1993. Synchronic large-scale disturbances and red spruce growth decline. Canadian Journal of Forest Research-Revue Canadienne De Recherche Forestiere, 23, 1361-1374.

Scanu RJ. 1988. Soil Survey of Berkshire County, Massachusetts.

Schweingruber FH. 1996. Tree Rings and Environment-Dendrochronology, Bern, Switzerland, Paul Haupt Verlag.

Scott JT, Siccama TG, Johnson AH, Breisch AR. 1984. Decline of red spruce in the Adirondacks, New York. Bulletin of the Torrey Botanical Club, 111, 438-444.

Shi CM, Masson-Delmotte V, Daux V, Li ZS, Zhang QB . 2010. An unstable tree-growth response to climate in two 500 year chronologies, North Eastern Qinghai-Tibetan Plateau. Dendrochronologia, 28, 225-237.

Siccama TG, Bliss M, Vogelmann HW. 1982. Decline of red spruce in the Green Mountains of Vermont. Bulletin of the Torrey Botanical Club, 109, 162-168.

Silver WL, Siccama TG, Johnson C, Johnson AH. 1991. Changes in red spruce populations in montane forests of the Appalachians, 1982-1987. American Midland Naturalist, 125, 340347.

Smith MD. 2011. An ecological perspective on extreme climatic events: a synthetic definition and framework to guide future research. Journal of Ecology, 99, 656-663.

Speer, JH. 2010. Fundamentals of tree-ring research, Tucson, USA, University of Arizona Press.

Treyger AL, Nowak CA. 2011. Changes in tree sapling composition within powerline corridors appear to be consistent with climatic changes in New York State. Global Change Biology, 17, 3439-3452. 
557

558

559

560

561

562

563

564

565

566

567

568

569

570

571

572

573

574

575

576

577

578

579
Van Deusen PC. 1987. Testing for stand dynamics effects on red spruce growth trends. Canadian Journal of Forest Research, 17, 1487-1495.

Van Deusen PC. 1990. Stand dynamics and red spruce decline. Canadian Journal of Forest Research-Revue Canadienne De Recherche Forestiere, 20, 743-749.

Van Deusen PC, Reams GA, Cook ER. 1991. Possible red spruce decline- contributinos of treering analysis. Journal of Forestry, 89, 20-24.

Van Doorn NS, Battles JJ, Fahey TJ, Siccama TG, Schwarz PA (2011) Links between biomass and tree demography in a northern hardwood forest: a decade of stability and change in Hubbard Brook Valley, New Hampshire. Canadian Journal of Forest Research-Revue Canadienne De Recherche Forestiere, 41, 1369-1379.

Vellinga P, Van Verseveld WJ. 2000. Climate Change and Extreme Weather Events. pp Page, Gland, Switzerland, World Wide Fund for Nature . Formerly World Wildlife Fund..

Webb SL, Glenn MG, Cook ER, Wagner WS, Thetford RD. 1993. Range edge red spruce in New Jersey, USA- Bog versus upland population structure and climate responses. Journal of Biogeography, 20, 63-78.

Wilmking M, D'arrigo R, Jacoby GC, Juday GP. 2005. Increased temperature sensitivity and divergent growth trends in circumpolar boreal forests. Geophysical Research Letters, 32.

Wilmking M, Juday GP, Barber VA, Zald HSJ. 2004. Recent climate warming forces contrasting growth responses of white spruce at treeline in Alaska through temperature thresholds. Global Change Biology, 10, 1724-1736.

Yamaguchi DK. 1991. A simple method for cross-dating increment cores from living trees. Canadian Journal of Forest Research-Revue Canadienne De Recherche Forestiere, 21, 414-416. 


\section{Table 1 (on next page)}

Location and plot information for each CFI forest.

Location (decimal degrees) of each CFI forest. Note the number of plots at each forest. 


\begin{tabular}{lcccc} 
& Mount & October & Savoy Forest & Middlefield \\
& Greylock & Mountain & & Forest \\
\hline Latitude & 42.622364 & 42.358235 & 42.594551 & 42.401972 \\
Longitude & -73.181151 & -73.1771771 & -73.0288963 & 73.0808754 \\
Elevation & $678-959 \mathrm{~m}$ & $540-613 \mathrm{~m}$ & $528-724 \mathrm{~m}$ & $542 \mathrm{~m}$ \\
Number of plots & 7 & 5 & 4 & 1 \\
\hline
\end{tabular}




\section{Table 2 (on next page)}

Stand dynamics for overstory and understory tree species across CFI forests.

Species overstory relative importance values (IV; relative density ${ }^{*}$ relative dominance )/ha, and the most common sapling densities in the CFI forests. 


\begin{tabular}{lllll} 
& \multicolumn{1}{c}{ MG } & OM & SF & \multicolumn{1}{c}{ MF } \\
\cline { 2 - 5 } Overstory species & $2010(\%)$ & $2010(\%)$ & $2010(\%)$ & $2010(\%)$ \\
\hline Abies balsamea & 11.8 & 6.0 & 1.7 & 6.6 \\
Acer rubrum & 8.5 & 19.8 & 26.4 & 33.2 \\
Acer saccharum & 3.7 & - & 6.9 & - \\
Betula alleghaniensis & 13.2 & 6.0 & 5.7 & 11.4 \\
Betula papyrifera & 8.4 & 4.6 & 2.5 & 4.4 \\
Fagus grandifolia & 5.9 & 2.2 & 8.2 & - \\
Fraxinus americana & - & 0.4 & 7.8 & - \\
Picea rubens & 39.8 & 39.2 & 30.7 & 15.2 \\
Prunus serotina & 4.4 & 3.4 & 3.6 & - \\
Tsuga canadensis & - & 10.3 & 5.9 & 29.3 \\
Other species & 2.2 & 8.0 & 0.6 & - \\
\hline Saplings (Density/ha) & & & & \\
Abies balsamea & 185.4 & 154.5 & 617.9 & 12.4 \\
Acer pensylvanicum & 119.5 & 12.4 & 185.4 & - \\
Acer rubrum & - & 185.4 & - & 49.4 \\
Betula alleghaniensis & 49.4 & 129.8 & 80.3 & 37.1 \\
Fagus grandifolia & 61.8 & 271.9 & 278.0 & - \\
Ilex verticillata & - & - & - & 74.1 \\
Picea rubens & 262.0 & 143.4 & 216.3 & 74.1 \\
Pinus strobus & - & 185.4 & - & - \\
Tsuga canadensis & - & 86.5 & - & - \\
& & & &
\end{tabular}




\section{Table 3 (on next page)}

Stand basal area and density among forests over time.

Mean stand, red spruce, and non-spruce basal area and density within MG, OM, and SF forests over four sampling years. MF was excluded since it has $1 \mathrm{CFI}$ plot established in 2000. 


\begin{tabular}{llllllll} 
Forest & Year & Total.Stems & Spruce.Stems & Non.spruce.Stems & Total.BA & Spruce.BA & $\begin{array}{l}\text { Non.spruce. } \\
\text { BA }\end{array}$ \\
\hline MG & 1960 & $87.63( \pm 15.86)$ & $137.99( \pm 49.37)$ & $76.43( \pm 15.73)$ & $9.41( \pm 1.92)$ & $19.85( \pm 7.42)$ & $7.09( \pm 1.44)$ \\
MG & 1980 & $86.5( \pm 15.80)$ & $133.87( \pm 48.75)$ & $76.35( \pm 15.95)$ & $9.64( \pm 2.01)$ & $21.11( \pm 8.24)$ & $7.19( \pm 1.42)$ \\
MG & 2000 & $86.5( \pm 18.65)$ & $148.29( \pm 52.62)$ & $74.15( \pm 19.41)$ & $11.03( \pm 2.56)$ & $28.06( \pm 11.10)$ & $7.63( \pm 1.69)$ \\
MG & 2010 & $88.2( \pm 21.98)$ & $181.24( \pm 44.06)$ & $69.03( \pm 23.65)$ & $4.03( \pm 0.99)$ & $11.26( \pm 4.11)$ & $2.54( \pm 0.59)$ \\
OM & 1960 & $109.51( \pm 20.72)$ & $271.87( \pm 27.26)$ & $67.16( \pm 15.84)$ & $10.06( \pm 2.31)$ & $31.22( \pm 3.87)$ & $4.54( \pm 0.97)$ \\
OM & 1980 & $98.86( \pm 21.15)$ & $225.97( \pm 62.88)$ & $64.64( \pm 15.83)$ & $9.85( \pm 1.98)$ & $25.98( \pm 4.39)$ & $5.51( \pm 1.26)$ \\
OM & 2000 & $89.12( \pm 19.46)$ & $175.48( \pm 61.84)$ & $73.70( \pm 19.23)$ & $8.21( \pm 2.20)$ & $22.21( \pm 10.16)$ & $5.71( \pm 1.58)$ \\
OM & 2010 & $72.09( \pm 11.66)$ & $86.5( \pm 27.07)$ & $69.20( \pm 13.03)$ & $4.94( \pm 1.10)$ & $11.32( \pm 3.12)$ & $3.67( \pm 1.04)$ \\
SF & 1960 & $68.48( \pm 14.78)$ & $168.89( \pm 69.30)$ & $54.14( \pm 11.68)$ & $4.93( \pm 1.38)$ & $15.53( \pm 8.40)$ & $3.41( \pm 0.75)$ \\
SF & 1980 & $75.63( \pm 17.26)$ & $259.51( \pm 12.36)$ & $50.55( \pm 11.64)$ & $7.52( \pm 2.19)$ & $33.41( \pm 6.41)$ & $3.99( \pm 0.85)$ \\
SF & 2000 & $74.60( \pm 15.52)$ & $168.89( \pm 66.29)$ & $61.20( \pm 13.47)$ & $7.94( \pm 2.39)$ & $27.31( \pm 14.79)$ & $5.17( \pm 1.15)$ \\
SF & 2010 & $67.04( \pm 12.37)$ & $131.81( \pm 53.55)$ & $55.61( \pm 9.23)$ & $4.35( \pm 1.28)$ & $11.28( \pm 7.08)$ & $3.05( \pm 0.61)$
\end{tabular}




\section{Figure 1}

Map of sampled forests and red spruce distribution.

Map of site locations in western Massachusetts, with key forests highlighted in green. Inset shows the complete range of red spruce.

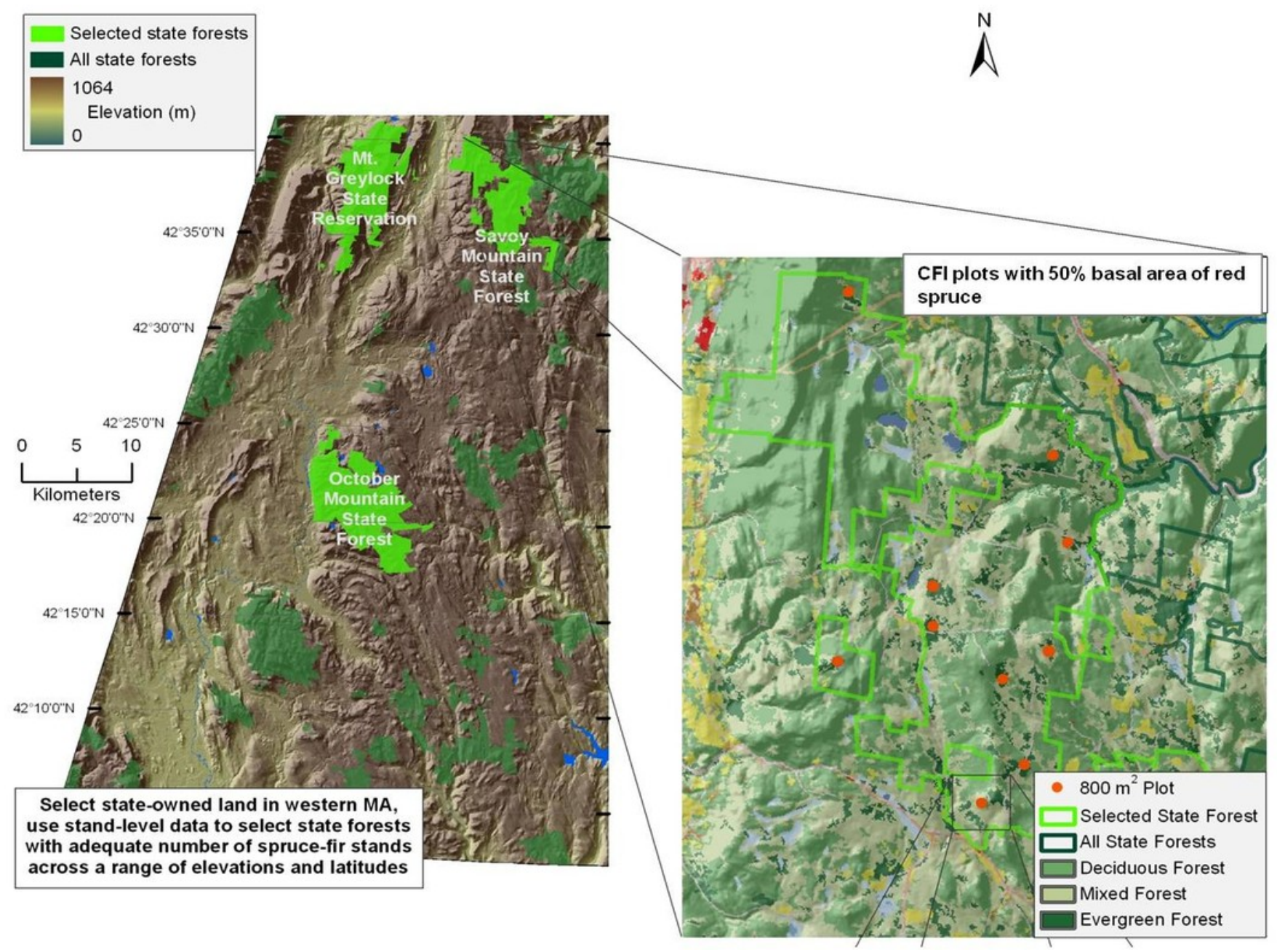




\section{Figure 2}

Basal area and density for all trees, red spruce only, and non-red spruce trees among the four forests over time.

(a) Total basal area of trees (m2/ha), (b) basal area of red spruce, (c) basal area of nonspruce species (d) Total stand density (stems/ha), (e) density of red spruce, and (f) density of non-red spruce in MG (black circle), OM (open circle), SF (grey circle), and MF (open diamond) forests across sampling years.
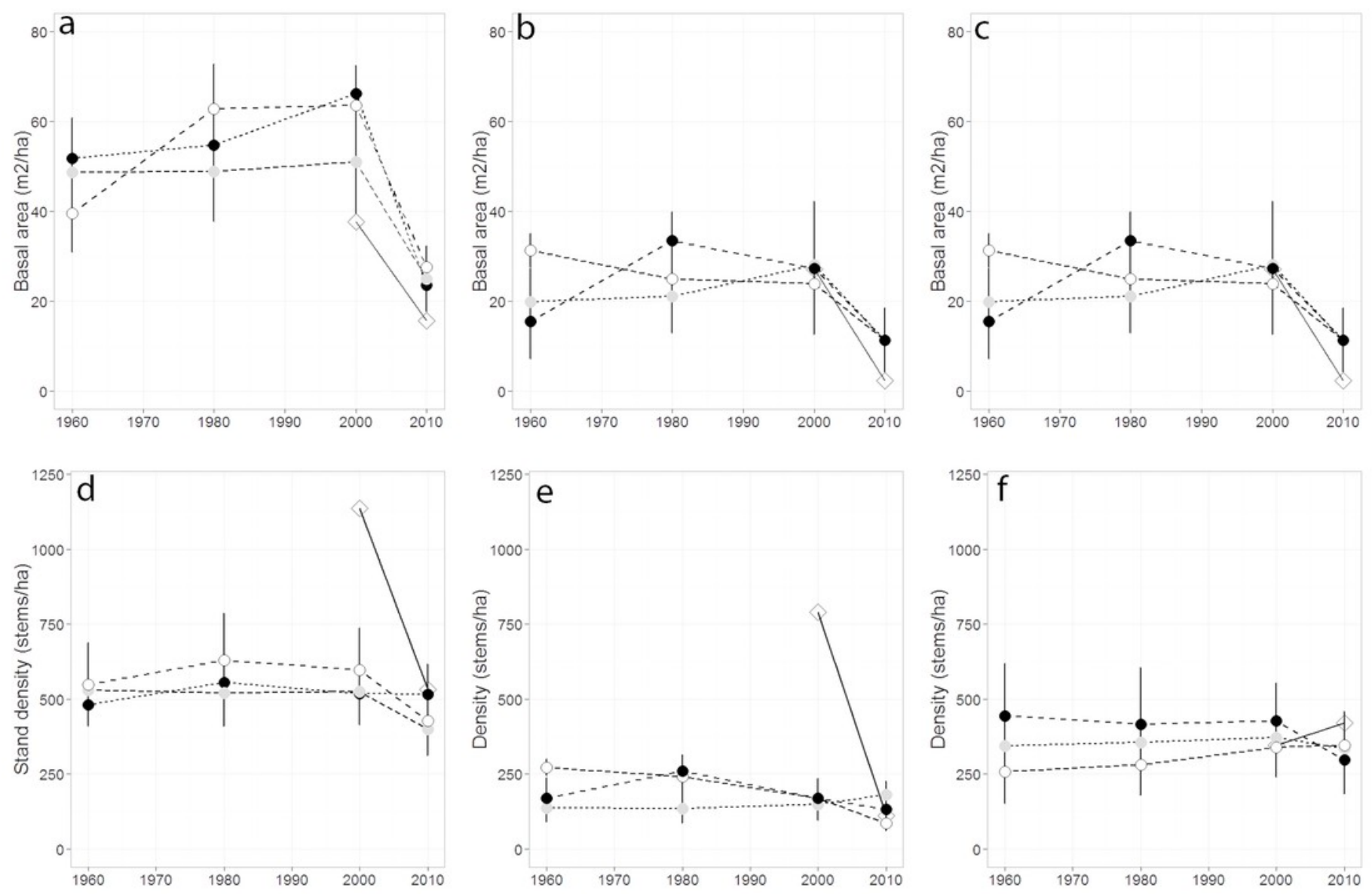


\section{Figure 3}

DendroClim maximum and minimum temperature correlations with forest chronologies.

Moving interval analysis graphs from DendroClim showing correlations between a site's ARSTAN chronology and maximum (top four graphs) and minimum (bottom graphs) monthly temperatures for that site. 

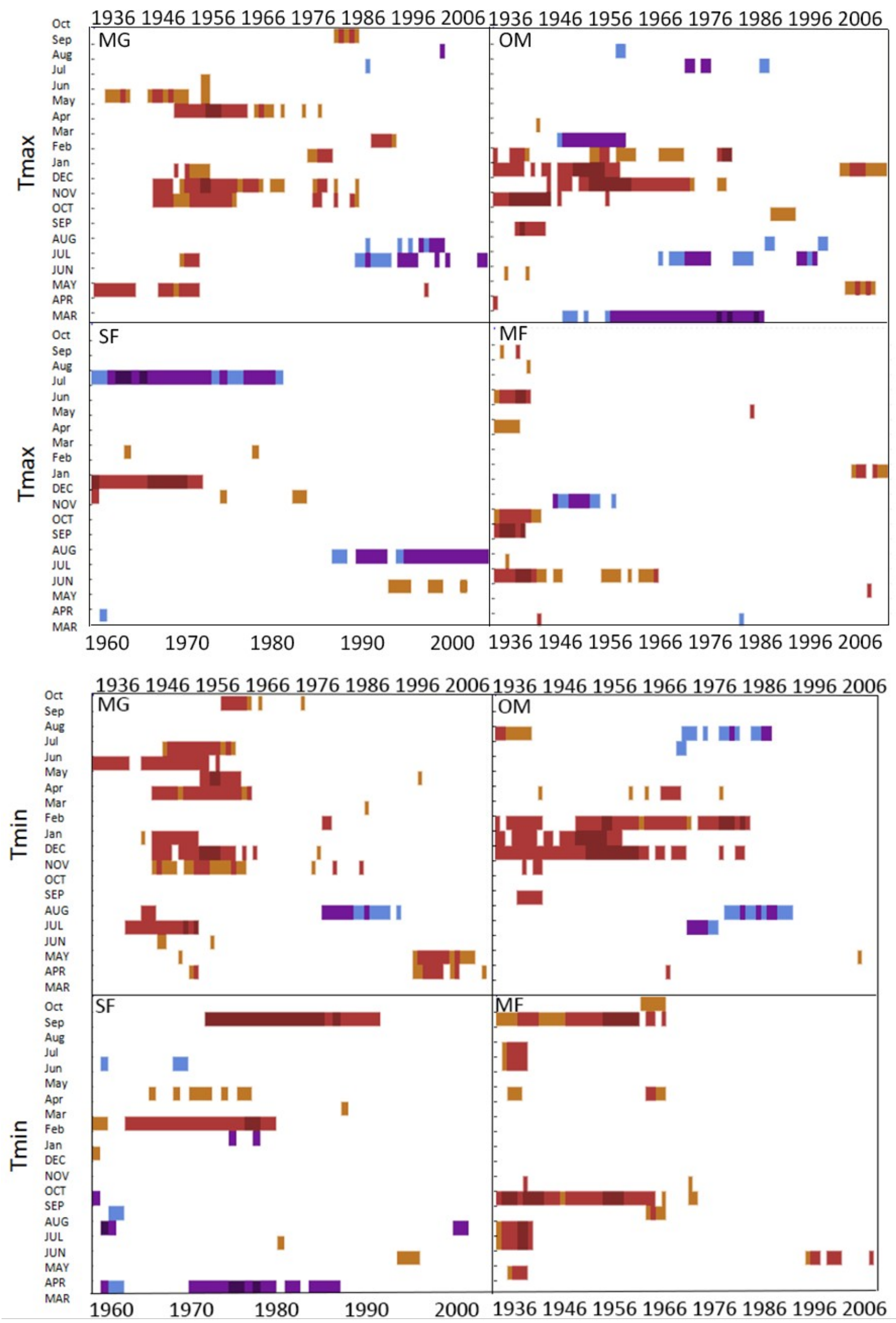

PeerJ reviewing PDF | (v2013:07:655:1:0:NEW 30 Nov 2013) 


\section{Figure 4}

Dendroclim precipitation correlations with with forest chronologies.

Moving interval analysis graphs from DendroClim showing correlations between a site's residual chronology and monthly precipitation for each forest.

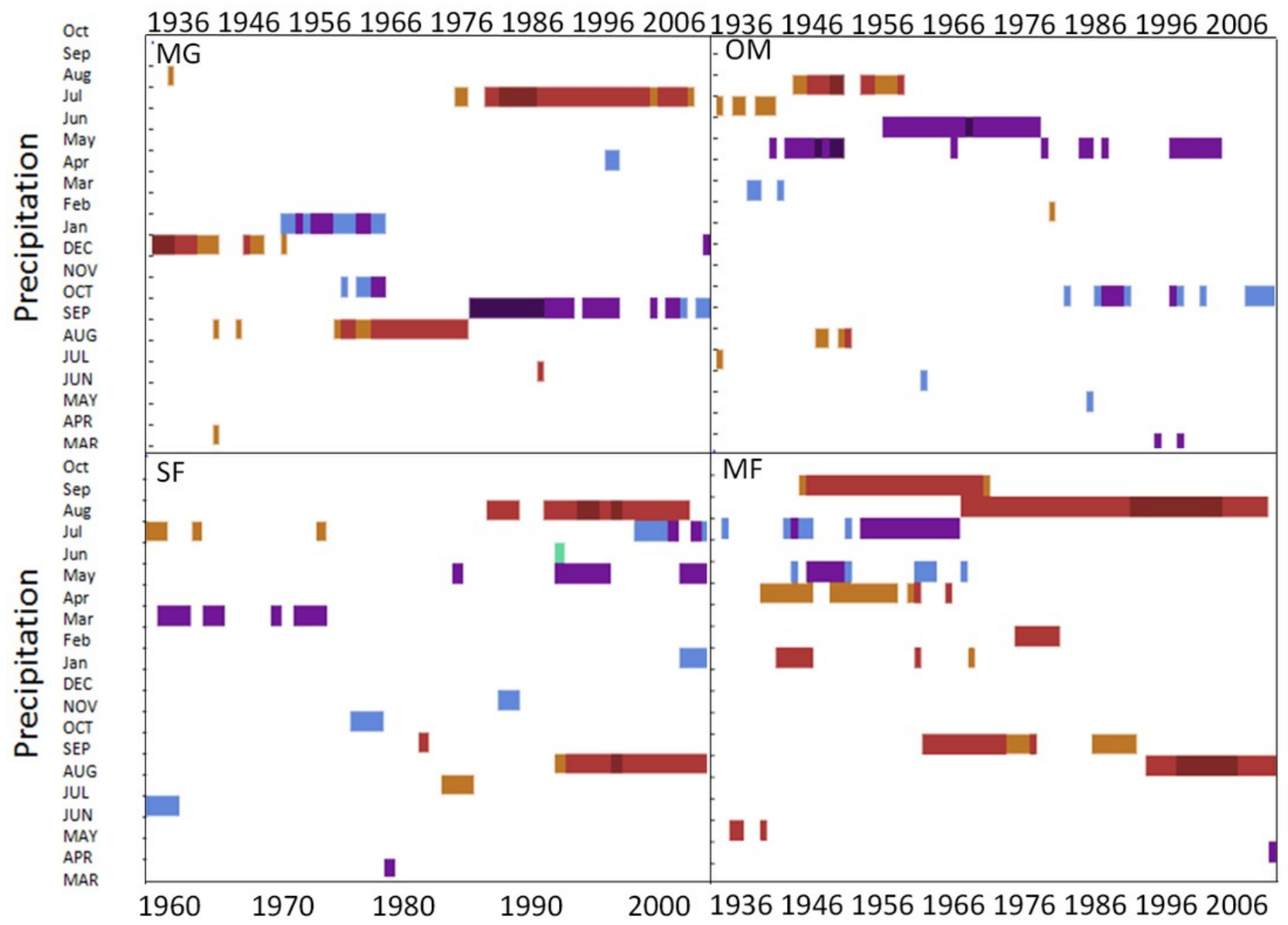




\section{Figure 5}

DendroClim correlations with temperature and precipitation with the regional tree-ring chronology.

Regional ARSTAN moving interval analysis in DendroClim, showing correlations across all forests combined into one chronology correlated with the regional climate (maximum and minimum temperatures, and precipitation). 


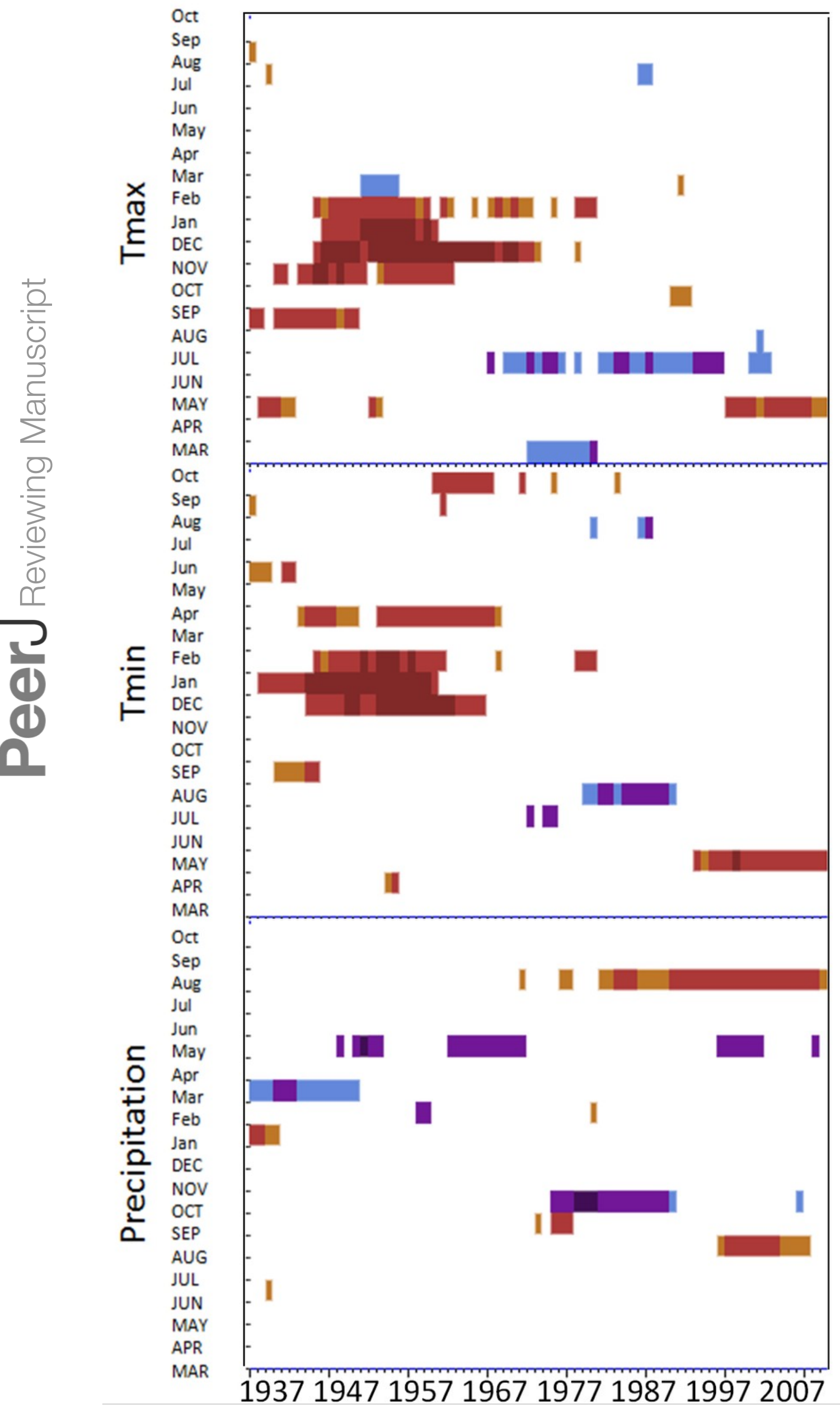

PeerJ reviewing PDF | (v2013:07:655:1:0:NEW 30 Nov 2013) 


\section{Figure 7}

Response function analyses for regional ARSTAN chronology with maximum and minimum monthly temperatures and precipitation.

Response function analyses for the regional ARSTAN chronology showing the period response for red spruce over previous year's climate parameters (months shown in capitals) and current year's climate parameters, with black bars indicating significant responses with maximum and minimum temperatures and precipitation (Tmax, Tmin, Precip). 

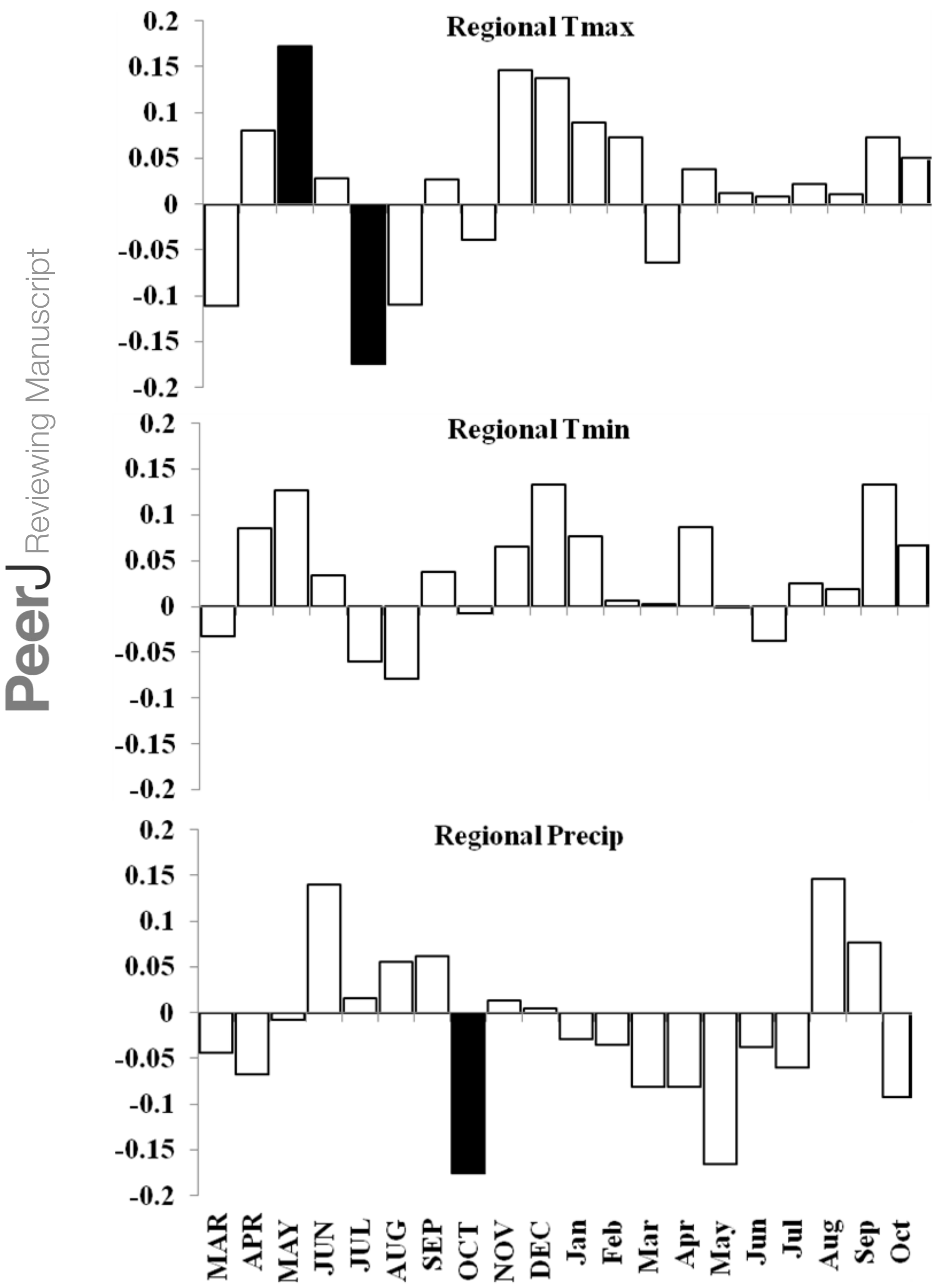


\section{Figure 8}

Decadal disturbance chronologies for each forest.

Disturbance chronology with decadal distribution of radial growth increases and abrupt decreases (see Methods for criteria) measured in tree cores from four red spruce stands in western Massachusetts. Dashed line represents the sampling depth at each site. 

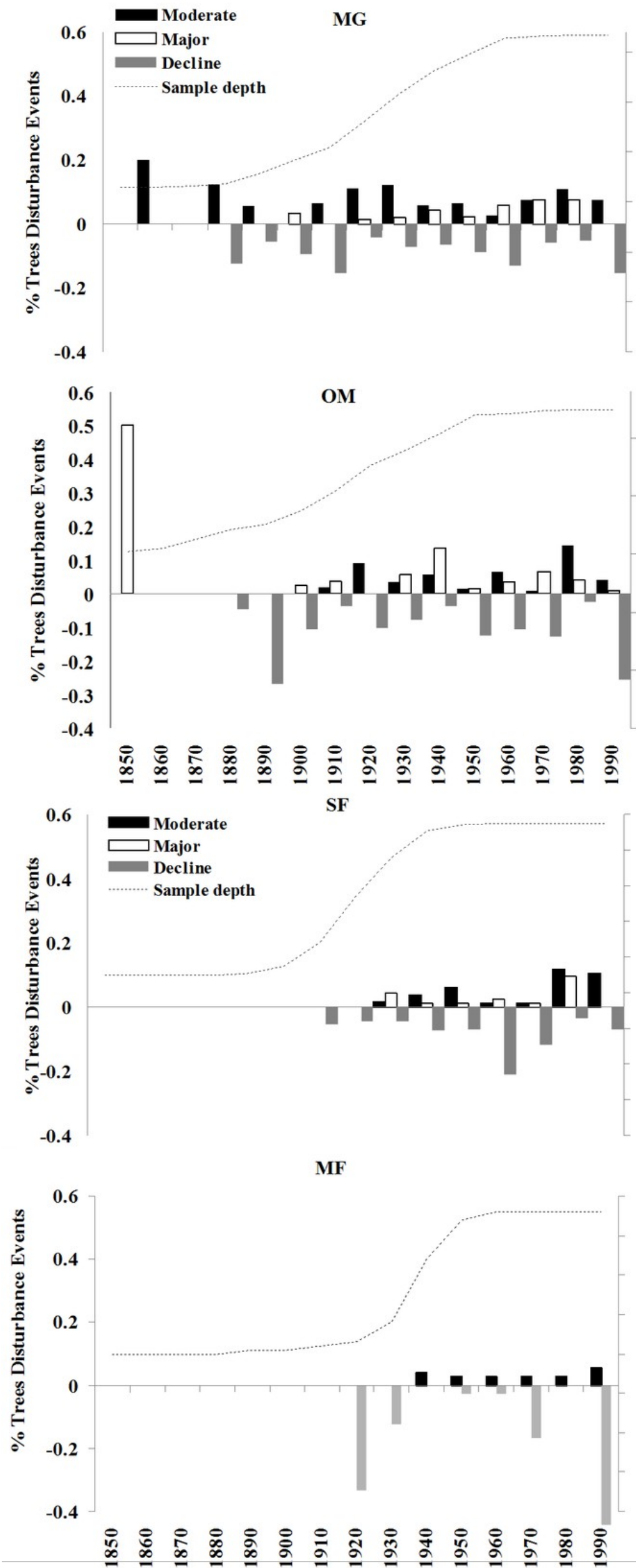

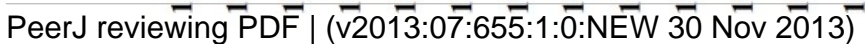

